\title{
Evaluation of shear strength parameters of rail track ballast in Sri Lanka
}

\author{
D.M.A.G.B. Dissanayake*, L.C. Kurukulasuriya and P.B.R. Dissanayake \\ Department of Civil Engineering, Faculty of Engineering, University of Peradeniya, Peradeniya.
}

\begin{abstract}
In Sri Lanka the ballasted rail tracks are the most preferred by the railway authority due to low initial investment and it continues using crushed rock as rail track ballast. Regardless of the frequent usage of these aggregates as track ballast in Sri Lanka, their shear strength characteristics have not been scientifically measured or used in design. The primary purpose of this paper is to present the investigation of shear strength properties of fresh and fouled rail track ballast in Sri Lanka using a large-scale direct shear device, which accommodates actual size ballast particles. The shear stress-strain and dilation behaviour of fresh and fouled ballast were obtained and the internal friction angle was estimated. The results showed that the shear strength of fresh ballast is higher than that of the fouled ballast and the shear strength envelope better resembled non-linear behaviour. Also it was revealed that the internal friction angle of ballast tends to reduce with age. More realistic shear strength parameters as proposed by the test results would promote state-of-the-art practice for the design of ballasted rail track foundations.
\end{abstract}

Keywords: Ballast, fouling, large scale testing, non-linearity, shear behaviour.

\section{INTRODUCTION}

Rail track ballast is the graded granular medium placed as the top layer of a rail track substructure in which the sleepers are embedded. It is widely accepted that open graded crushed aggregates are the most suitable as track ballast. Ballast is frequently subjected to higher stresses and exposed to severe weather conditions making it vulnerable to deterioration or fouling. The stability and performance of the rail track foundation is governed by the in situ state and engineering behaviour of the ballast. Therefore, understanding the shear strength parameters of the ballast material and the influence of ballast deterioration is essential in track substructure design and management.
It has long been recognised that open graded crushed aggregate as having properties that are most desirable for rail track ballast. An understanding of the primary tasks of rail track ballast, and how the ballast performs and their governing factors is essential in the design, construction and management of rail track systems. The prime expectation of good quality crushed angular rock fragments as rail track ballast is the ability to provide optimum resiliency, effective transmission of wheel loads to the subgrade and minimal plastic deformation in vertical, lateral and longitudinal directions (Chrismer, 1985; Jeffs \& Marich, 1987; Indraratna \& Salim, 2001). It should also ensure efficient drainage of the track, so that minimal or no excess pore water pressure is developed inside the ballast bed. These properties together with the ease of construction and low capital investment have led to the continued use of crushed stones as rail track ballast in railway transportation.

In Sri Lanka trains on ballasted rail tracks run at relatively low speeds with less hauling capacity, reducing the efficiency of one of the country's major mass transit systems. However, due to the growing demand for a safer and efficient rail transportation system, Sri Lanka Railways is expected to introduce new rail tracks and to transform the existing rail tracks, which are capable of accommodating trains running at $120 \mathrm{kmph}$ with greater hauling capacity. This will lead to an increased stress to the track components including the ballast bed, which require frequent maintenance work. Assessment of the stability of embankment, bearing capacity, lateral and longitudinal resistance are required shear strength parameters of ballast. Proper understanding of the shear strength properties of the ballast, which forms the major part of the track substructure is important. 
The most commonly used laboratory devices available to estimate the shear strength parameters of aggregates are the direct shear and tri-axial test apparatus, with direct shear test being the simplest and the frequently used. The current practice of testing rockfill material is by following the parallel gradation technique or the scalping technique due to the fact that common geotechnical apparatus readily available in laboratories are not capable of accommodating larger particle sizes (Asadzadeh \& Soroush, 2009; Rao et al., 2011). Considering the open graded nature of these materials, both techniques could significantly affect the reliability of strength parameters of coarse aggregates. Therefore, the best alternative is the use of large scale devices to assess the strength properties. Marsal (1967), Marachi et al. (1972), Charles and Watts (1980), Indraratne et al. (1998) and Cambio and Ge (2007) among others have evaluated shear strength parameters of rockfill and ballast material by testing large specimens at laboratories.

This paper presents the results of direct shear tests conducted on freshly quarried ballast and fouled ballast extracted from the track, using a large scale direct shear apparatus. The objective of the investigation is to provide experimental data on the shear stress-strain characteristics of fresh and fouled materials, and assess the friction angle values of fresh and fouled ballast.

\section{METHODS AND MATERIALS}

A series of direct shear tests were conducted on fresh and fouled ballast specimens under dry conditions. Each series consisted of four direct shear tests performed under four different surcharge pressures. Fresh biotite gneiss ballast samples were collected from a quarry near Peradeniya, Sri Lanka, which supplies ballast to Sri Lanka Railways (SLR) so that the material characteristics are consistent with the ballast in the field. Fresh ballast was air dried, cleaned and any particles with visible cracks were removed. The physical examination of fresh ballast indicated that almost $100 \%$ of the specimen comprised highly angular rock fragments. Table 1 shows the physical properties of fresh ballast.

Table 1: Physical properties of fresh ballast

\begin{tabular}{lc}
\hline Property & Test value \\
\hline Aggregate crushing value & $28 \%$ \\
Aggregate impact value & $35 \%$ \\
Water absorption & $0.194 \%$ \\
Bulk specific gravity & 2.68 \\
Flakiness index & $15 \%$ \\
Elongation index & $27 \%$ \\
\hline
\end{tabular}

Fouled ballast samples were extracted from the Peradeniya - Kandy rail track at $0.5 \mathrm{~km}$ post where the ballast layer is approximately three to four years old. The physical examination of air dried fouled ballast indicated that the specimen consisted of about $95 \%$ semi-angular crushed rock, materials migrated from subgrade and other impurities (organic materials, wagon spillage, sleeper waste etc.). The degree of fouling of ballast extracted from the field was assessed and expressed using 'percentage fouling' as suggested by Selig and Waters (1994) and modified by Anbazhagan et al. (2012) for Indian rail track ballast, since the current Sri Lankan ballast specifications have been adopted from the Specification for Track Ballast in India (IRS-GE-1-2004). Anbazhagan et al. (2012) suggested that material passing a $20 \mathrm{~mm}$ sieve could be treated as fines or fouling material and the percentage of fouling was estimated by taking the ratio of the dry weight of material passing a $20 \mathrm{~mm}$ sieve to the dry weight of the total sample. The evaluated percentage fouling of the fouled ballast was found to be $17 \%$ and could be considered as moderately fouled since it is between 9.5 and $17.5 \%$ (Anbazhagan et al., 2012).

Fresh ballast specimens (dry) for the test were prepared conforming to the lower limit of aggregate size distribution as specified in the Manual of Special Rules (Sri Lanka Railways, 2004). Fouled ballast specimens were air dried and cleaned for impurities by visual examination. Particle size distribution curves of fresh and fouled ballast used in the study are shown in Figure 1.

The large scale direct shear apparatus used in this study could accommodate a $400 \mathrm{~mm}$ diameter $300 \mathrm{~mm}$ high aggregate sample. The test device is capable of shearing the sample into two equal halves in a similar manner to the conventional system. The top loading plate of the device is free to move vertically and the normal load was applied using static weights system similar to that in the conventional test apparatus. Vertical movement of the top plate was measured using a displacement transducer attached to the centre of the loading plate and the shear displacement was measured by another displacement transducer horizontally aligned to a side of the lower part of the shear device. Similarly, the resistance to shearing was measured by a load cell attached to the top part of the shear apparatus and the data was acquired by a data logger connected to a computer. Shear force to the lower half was applied continuously by a hydraulic loading system at a displacement rate of $4 \mathrm{~mm} / \mathrm{min}$, while the upper half remained stationary. The schematic diagram of the large scale direct shear apparatus and the test setup used in this study is given in Figure 2. 


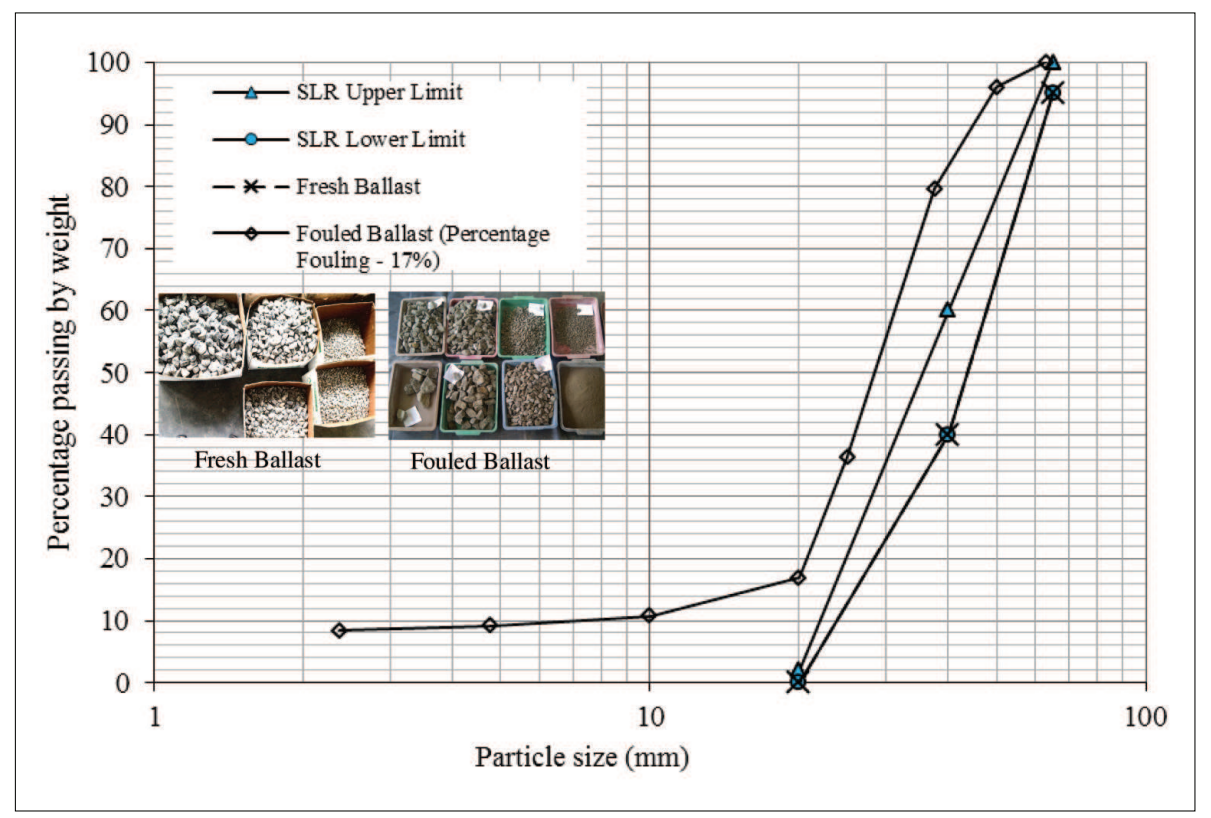

Figure 1: Particle size distributions of ballast specimen used in the study with upper and lower limits of Sri Lanka Railways (SLR) ballast specification; Inset-images of fresh and fouled ballast separated into size fractions

Based on ASTM D3080-03 the maximum particle size for direct shear testing is limited to 0.1 of apparatus diameter. In this test, the maximum particle size of the ballast was $65 \mathrm{~mm}$, which is $5 \%$ of the test sample. Thus, the ratio of maximum particle size to the device diameter is 0.16 , which exceeds the specified limit in ASTM D3080-03. However, Fakhimi and Hosseinpour (2008) have proposed that for low normal stresses this limit could be relaxed to 0.20 for cohesionless materials with minimal increase in the friction angle. A predetermined amount of dry ballast was placed in four $75 \mathrm{~mm}$ thick layers and compacted to achieve the field unit weight

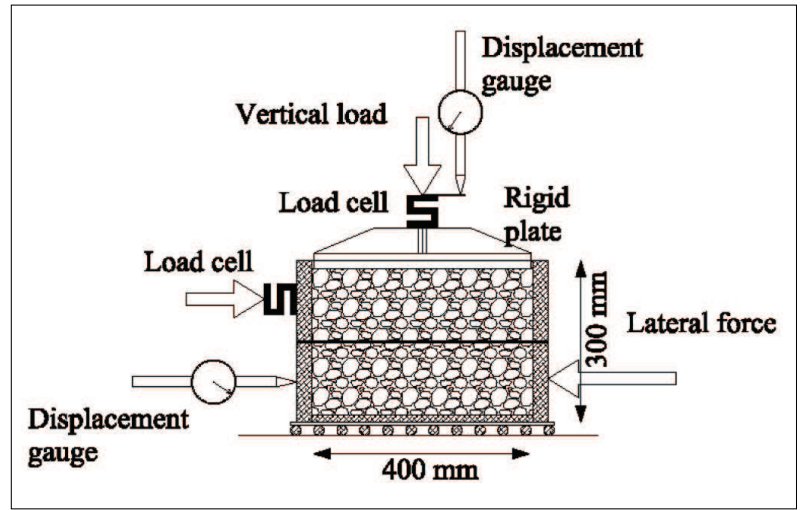

Figure 2: Schematic diagram of the large scale direct shear setup used in the study of $16.1 \mathrm{kN} / \mathrm{m}^{3}$. A fibre mat placed on the aggregate layer was used to avoid damage to aggregates during the compaction stage. Figure 3 shows an image of fresh and fouled ballast specimens inside the shear box during the compaction stage. The tests were performed under surcharge pressures of 15, 30, 61 and $92 \mathrm{kPa}$. The range of normal pressure was selected so that it represents the normal stresses of ballast in track shoulders and ballast bed at the passage of a train (Rujikiatkamjorn et al., 2012). The specimens were sheared until a $60 \mathrm{~mm}$ maximum displacement is reached corresponding to $15 \%$ shear strain.

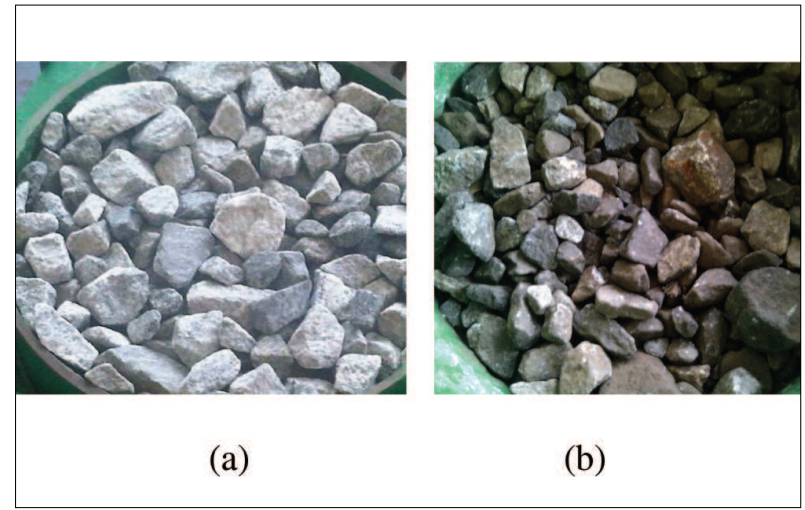

Figure 3: Air dried (a) fresh and (b) fouled ballast specimens in the shear box 


\section{RESULTS AND DISCUSSION}

Figures 4 and 5 illustrate the shear stress and vertical displacement against shear strain of fresh and fouled ballast specimens under normal stresses varying from 15 to $92 \mathrm{kPa}$. Shear stress versus shear strain curves for both fresh and fouled ballast specimens indicated only a slight peak behaviour. The peak shear stress occurred between $5 \%$ and $10 \%$ of shear strain for all normal stresses and indicated a strain softening behaviour after attaining the peak shear stress. In addition, all samples exhibited a more dilative behaviour at low normal stresses and a slight initial contraction followed by a dilative behaviour at high normal stresses. This behaviour is compatible with the shear stress-strain behaviour reported by Marsal (1967), Marachi et al. (1972), Rao et al. (2011) and Ghanbari et al. (2013) for rockfill material and by Indraratne et al. (1998) and Indraratne and Salim (2001) for rail track ballast.

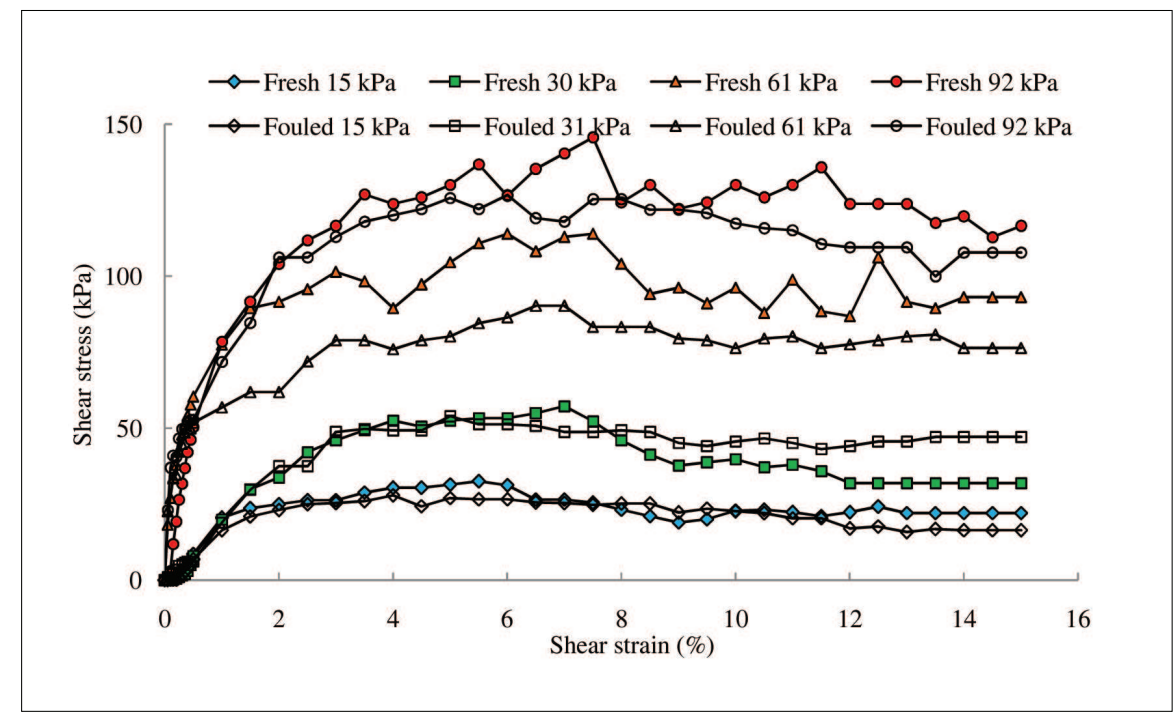

Figure 4: Shear stress-strain behaviour of dry fresh and fouled ballast

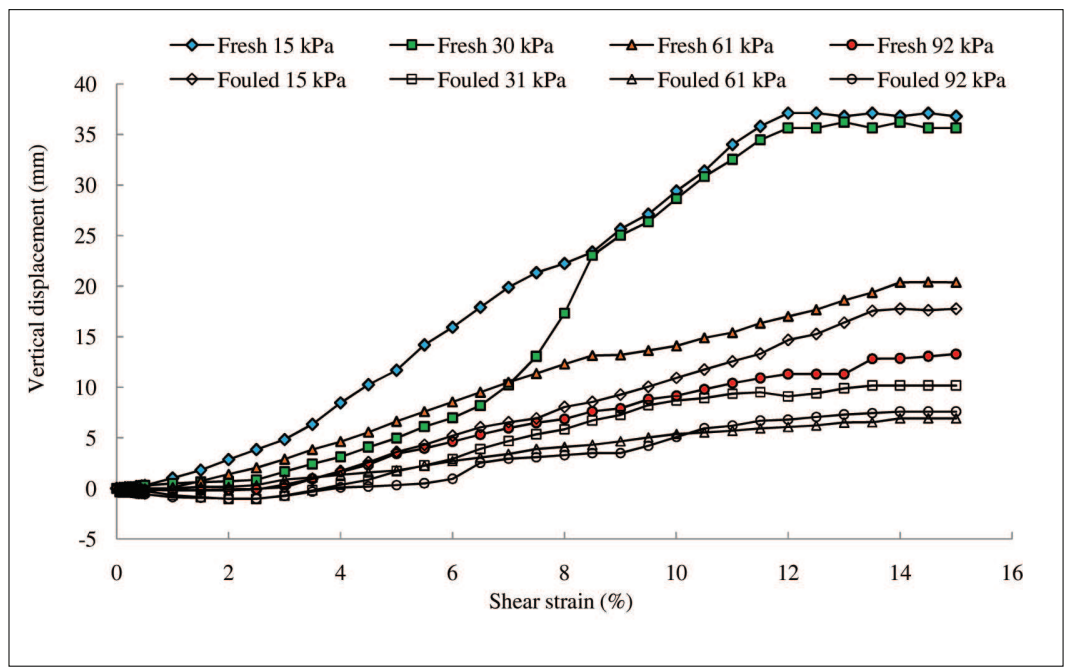

Figure 5: Vertical displacement - shear strain behaviour of dry fresh and fouled ballast 
The results show that both the shear stress and dilation of fresh ballast are comparatively higher compared to that of the fouled ballast. The high shear resistance of fresh ballast could be attributed to the higher interlocking action provided by more angular particles with sharp edges, and the frictional resistance provided by comparatively rough surfaces of freshly quarried ballast grains. Reduced shear resistance of fouled ballast is attributed to the lack of sharp edges, reducing the effective interlocking of grains and smoothened aggregate surfaces providing less frictional resistance. The breaking off of sharp edges and the smoothening of aggregate extracted from the track was caused by the loading applied from trains and exposure to severe weather conditions. The sharp fluctuations seen in shear stress-shear strain curves of fresh ballast at 61 and $92 \mathrm{kPa}$ normal stresses could be attributed to the failure of sharp edges of the fresh ballast particles at shearing. These sharp fluctuations were not observed for fouled ballast at the same surcharge indicating the more spherical nature of fouled ballast grains. Also, the finer fouling material from subgrade migration could coat the surface of aggregate grains and inhibit interparticle friction contributing to further reduction of shear resistance.

Figure 5 illustrates the vertical displacement-shear strain behaviour of fresh and fouled ballast. The dilation is initiated with the subsequent shearing as ballast grains are compressed to a threshold packing arrangement. It was observed that the dilation of fresh ballast was considerably higher than that of fouled ballast for the tested range of normal stresses.
This difference could be attributed to the particle size distribution and grain sizes of fresh and fouled ballast specimens since the initial densities of both specimens were the same. Particle size distribution shows that D50 (particle size for $50 \%$ finer) is $40 \mathrm{~mm}$ and $25 \mathrm{~mm}$ for fresh ballast and fouled ballast, respectively. Therefore, it could be suggested that comparatively larger grains in fresh ballast produced more dilation than that of the smaller grains in fouled ballast.

Figure 6 shows the peak shear stress-normal stress relationship based on linear Mohr-Coulomb (MC) envelops. It is observed that the use of linear MC approach resulted in a cohesion value, which is not consistent with cohesionless aggregates. The computed high cohesion values from linear Mohr-Coulomb approach should not exist for at least fresh ballast and for ballast fouled by a

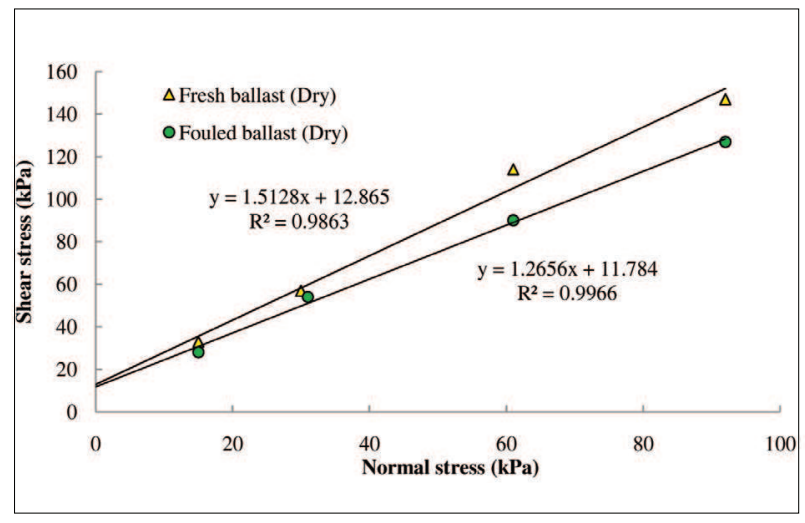

Figure 6: Linear Mohr Coulomb failure surface for fresh and fouled ballast

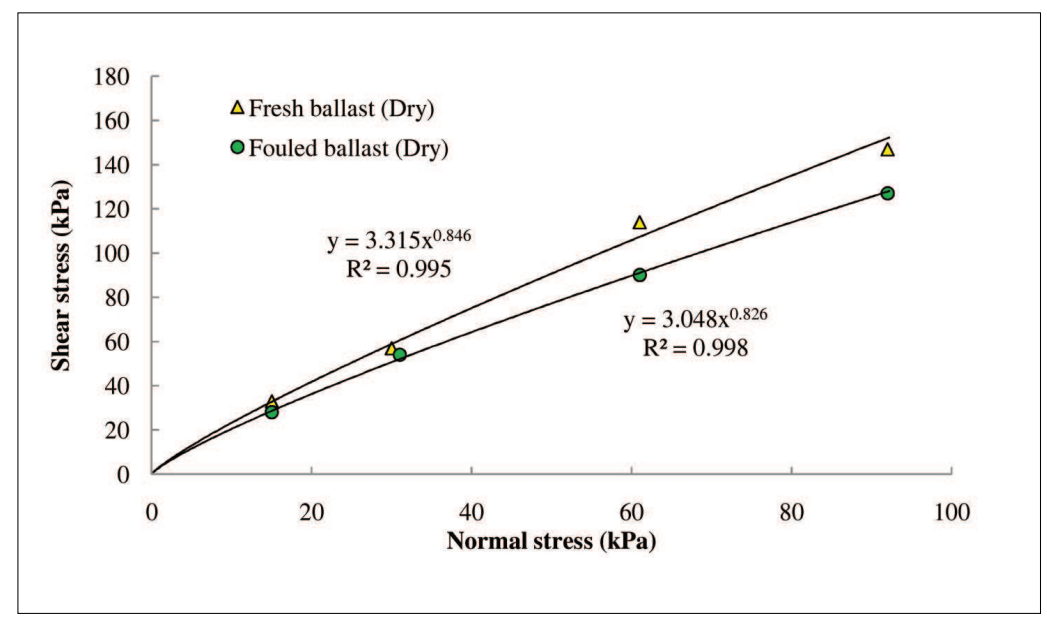

Figure 7: Non-linear Mohr Coulomb failure envelopes for fresh and fouled ballast 
moderate degree of particle breakage, as the material can be considered essentially as cohesionless. Indraratne et al. (1998) have stated that this inconsistency is due to the fact that the failure envelopes are actually non-linear and it is mainly due to the aggregate interlocking and dilation during the shearing. Marachi et al. (1972), Ramamurthy (2001) and Asadzadeh and Soroush (2009) among others have also shown that the shear strength envelop of coarse aggregates was non-linear based on the research of rock fill material. Therefore, Figure 7 illustrates the interpretation of results using non-linear Mohr-Coulomb envelope. It can be seen that the non-linear behaviour is the most suitable approach to describe the failure criteria of fresh and fouled ballast, which seems to even improve the coefficient of regression. According to Figure 7, it is clear that the friction angle $(\phi)$ values obtained from the non-linear $\mathrm{MC}$ approach vary from $65^{\circ}$ to $58^{\circ}$ for fresh ballast and $62^{\circ}$ to $54^{\circ}$ for fouled ballast depending on the applied normal stress.

The results obtained in this study indicate a reduction of the friction angle of ballast with fouling. Selig and Waters (1994), and Anbazhagan et al. (2012) have indicated that a gradual loss of shear strength could occur when the degree of ballast fouling with fines is increased. As the degree of fouling with fines develop during the service life, aggregate particles will be further separated and contacts will be lubricated with fines, producing weakened ballast structure with reduced shear strength.

\section{CONCLUSION}

Large scale direct shear tests were conducted on freshly quarried ballast and deteriorated ballast (percentage fouling $-17 \%$ ) to study the shear stress-strain behaviour at dry state.

The results demonstrated that the shear strength of fresh ballast was higher than that of fouled ballast. This is justified by the presence of effective interlocking of more angular particles with sharp edges in the fresh ballast specimen compared to the more spherical and smooth old ballast coated by fines migrated from the subgrade. The dilation of fouled ballast was considerably less than that of fresh ballast, and it is attributed to the reduced grain sizes in the fouled ballast assembly due to breakage of aggregate at the passage of trains and exposure to weather.

The results demonstrated that shear strength envelops of tested materials better resembled a non-linear behaviour.
The friction angles of fresh and fouled ballast were determined using the non-linear Mohr-Coulomb approach. Measured friction angle values varied from $65^{\circ}$ to $58^{\circ}$ for fresh ballast and $62^{\circ}$ to $54^{\circ}$ for fouled ballast for the applied normal stress range.

\section{Acknowledgement}

The authors express their sincere gratitude to the financial assistance given by the National Research Council (NRC) of Sri Lanka.

\section{REFERENCES}

1. Anbazhagan P., Bharatha T.P. \& Amarajeevi G. (2012). Study of ballast fouling in railway track formations. Indian Geotechnical Journal 42(2): 87 - 99.

DOI: http://dx.doi.org/10.1007/s40098-012-0006-6

2. Asadzadeh M. \& Soroush A. (2009). Direct shear testing on a rock fill material. The Arabian Journal for Science and Engineering 34(2B): 379 - 396.

3. ASTM D3080 (1998). Standard test method for direct shear test of soils under consolidated drained conditions. ASTM International, West Conshochocken, USA.

4. Cambio D. \& Ge L. (2007). Effects of parallel gradation on strength properties of ballast materials. Advances in Measurement and Modelling of Soil Behaviour (GSP173): $1-7$.

5. Charles J.A. \& Watts K.S. (1980). The influence of confining pressure on the shear strength of compacted rockfill. Geotechnique 30(4): 353 - 367.

6. Chrismer S.M. (1985). Consideration of factors affecting ballast performance. AAR Research and Test Department Report No. WPl10. AREA Bulletin 704, pp. 118 - 150. Transportation Technology Center, Inc., Pueblo, USA.

7. Fakhimi A. \& Hosseinpour H. (2008). The role of oversize particles on the shear strength and deformational behaviour of rock pile material. Proceedings of the $42^{\text {nd }}$ US. Rock Mechanics Symposium, 29 June - 2 July, San Francisco, CA, USA.

8. Ghanbari A., Hamidi A. \& Abdolahzadeh N. (2013). A study of the rockfill material behaviour in large-scale tests. Civil Engineering Infrastructures Journal 46(2): 125 -143 .

9. Indraratna B., Ionescu D. \& Christie H.D. (1998). Shear behaviour of railway ballast based on large-scale triaxial tests. Journal of Geotechnical and Geoenvironmental Engieering 124(5): 439 - 449.

10. Indraratna B. \& Salim W. (2001). Shear strength and degradation characteristics of railway ballast. Proceedings of the $14^{\text {th }}$ Southeast Asian Geotechnical Conference, 10 - 14 December, Hong Kong, pp. 521 - 526. 
11. IRS-GE-1(2004). Indian Specification for Rail Track Ballast. Ministry of Railways, Government of India.

12. Jeffs T. \& Marich S. (1987). Ballast characteristics in the laboratory. Proceedings of the Conference on Railway Engineering, 14 - 16 September, Perth, Australia, pp. $141-147$.

13. Marachi N.D., Chan C.K. \& Seed H.D. (1972). Evaluation of properties of rock fill materials. Journal of Soil Mechanics and Foundations 98: 95 - 114.

14. Marsal R.J. (1967). Large-scale testing of rockfill materials. Journal of Soil Mechanics and Foundation Divisions ASCE 93(2): $27-43$.

15. Ramamurthy T. (2001). Shear strength response of some geological materials in triaxial compression. International Journal of Rock Mechanics and Mining Sciences 38: $683-697$.
16. Rao S.V., Bajaj S. \& Dhanote S. (2011). Evaluations of strength parameters of rockfill material for Pakaldul hydroelectric project, Jammu and Kashmir- a case study, Proceedings of the Indian Geotechnical Conference, 15 - 17 December, Kochi, India, pp. 991 - 994.

17. Rujikiatkamjorn C., Indraratna B., Ngo N. \& Coop M. (2012). A laboratory study of railway ballast behaviour under various fouling degree. $5^{\text {th }}$ Asian Regional Conference on Geosynthetics, pp. $507-514$.

18. Selig T. \& Waters M. (1994). Track Geotechnology and Substructure Management. Thomas Telford Publications, 1 Heron Quay, London, UK.

DOI: http://dx.doi.org/10.1680/tgasm.20139

19. Sri Lanka Railways (2004). Manual of Special Rules, Part I, Permanent Way, Way and Works Department. Sri Lanka Railways. 